\title{
PELATIHAN PEMANFAATAN BARANG BEKAS MENJADI BARANG YANG BERNILAI EKONOMI
}

\author{
Rizqy Fadhlina Putri ${ }^{1}$ ), Rini Fadhillah Putri ${ }^{2}$ ) \\ Universitas Muslim Nusantara (UMN) Al Washliyah Medan \\ Jl.Garu II A No. 93 Medan \\ rizqy.fadhlinaputri@gmail.com
}

\begin{abstract}
ABSTRAK
Dengan diadakannya pelatihan kreasi upaya pemanfaatan barang bekas menjadi kerajinan tangan di Desa Doulu, Kecamatan Brastagi Kabupaten Karo diharapkan akan meningkatkan kreatifitas masyarakat guna menunjang perekononian dan menjadi daya tarik pengunjung sebagai kota wisata. Melalui pelatihan kreasi ini masyarakat lebih punya pengetahuan mengenai peluang usaha yang dapat tercipta melalui kreatifitas dan keterampilan tersebut agar barang bekas yang mereka kreasikan dapat mempunyai nilai ekonomi yang tinggi. Pelatihan kreasi dilaksanakan melalui beberapa tahap yaitu dengan pemberian materi serta pengetahuan, dalam pelaksanaan pelatihan kreasi nantinya peserta akan dibimbing untuk dapat berkreasi membuat berbagai kerajinan tangan. Kemudian hasil kerajinan tangan akan di jual ke pasar atau toko oleh peserta pelatihan kreasi.
\end{abstract}

Kata Kunci: Barang Bekas, Barang Bernilai Ekonomi

\begin{abstract}
By having the creation of training the effort to utilize used goods into handicrafts in Doulu Village, Brastagi Sub-District Karo Regency is expected to increase the creativity of the community in order to support the reconstruction and become the visitor attraction as a tourist city. Through this creative training, the community is more knowledgeable about the business opportunities that can be created through creativity and skills so that their used goods can have high economic value. Creative training is carried out through several stages, namely by providing materials and knowledge, in the implementation of creative training the participants will be guided to be able to create various handicrafts. Then the handicrafts will be sold to the market or shop by the creative training participants. Keywords: Used Goods, Economic Value Goods
\end{abstract}


1. Pendahuluan

1.1 Judul Program

Pelatihan Kreasi :

Pelatihan Pemanfaatan barang bekas menjadi barang yang bernilai ekonomi

\subsection{Latar Belakang}

Dewasa ini, sampah menjadi salah satu permasalahan yang cukup sulit di tangani di Indonesia. Hal ini terjadi karena kebiasaan masyarakatnya sebagai konsumen yang selalu menghasilkan sampah. Oleh karena itu dengan mengubah barang bekas terutama koran atau kertas-kertas bekas menjadi barang yang dapat digunakan kembali dapat membantu mengurangi pencemaran lingkungan.

Kreativitas pemanfaatan barang bekas menjadi kerajinan tangan adalah solusi yang cukup baik untuk mengubah sampah kertas menjadi menjadi barang yang berguna kembali, bahkan memiliki nilai jual serta dapat dikreasikan menjadi barang yang mempunyai nilai estetika. Kreativitas dalam diri seseorang dapat ditumbuhakan melalui banyak cara, salah satunya yaitu dengan membuat kerajinan tangan. Sampah kertas dapat dibuat kerajinan tangan seperti hiasan kamar, lampu hias, tempat pensil, keranjang, dan lain lain.

$$
\text { Pemanfaatan sampah }
$$

kertas masih jarang dilakukan di daerah yang masyarakatnya kurang memperhatikan hal-hal seperti kreativitas kerajinan tangan dengan memanfaatkan sampah. Dengan adanya program kegiatan pelatihan kreativitas pemanfaatan sampah kertas menjadi kerajinan tangan ini diharapkan masyarakat dapat meningkatkan kepedulian terhadap lingkungan dengan memanfaatkan sampah, selain itu masyarakat dapat mempunyai keterampilan dalam hal kreativitas serta dapat meningkatkan kesadaran terhadap lingkungan.

\subsection{Rumusan Masalah}

1. Bagaimana memberikan pengetahuan kepada masyarakat agar mau memanfaatkan sampah kertas atau barang bekas yang ada di lingkungannya?

2. Bagaimana mengadakan pelatihan kreasi terkait cara membuat kerajinan tangan dengan berbahan dasar kertas?

3. Bagaimana memberikan pengetahuan kepada masyarakat bahwa produk kreasi pemanfaatan barang bekas dapat meningkatkan pendapatan?

\section{TARGET DAN LUARAN}

\subsection{TARGET} adalah

Target dari kelas pelatihan kelas

1. Memberikan pengetahuan sekaligus pelatihan kepada masyarakat mengenai pemanfaatan barang bekas menjadi kerajinan tangan.

2. Memberikan pengetahuan tentang peluang usaha yang dapat tercipta dengan adanya keterampilan membuat kerajinan tangan untuk meningkatkan pendapatan.

3. Meningkatkan kreatifitas masyarakat dalam pemanfaatan barang bekas

4. Meminimalisir pencemaran lingkungan dengan memanfaatkan sampah. 


\subsection{LUARAN}

Program ini sebagai bentuk pengabdian masyarakat dengan mengadakan kegiatan pelatihan dalam pelatihan kreasi upaya pemanfaatan barang bekas menjadi kerajinan tangan, luaran yang diharapkan :

1. Masyarakat diharapkan mampu dan terampil dalam membuat kerajinan tangan berbahan dasar kertas dan memiliki kreativitas dalam memanfaatkan barang bekas.

2. Memberdayakan masyarakat agar dapat mengembangkan kreativitasnya melalui pelatihan membuat kerajinan tangan yang bernilai jual sehingga dapat meningkatkan penghasilan mereka.

3. Masyarakat akan kebersihan lingkungan sehingga dapat meminimalisir dampak negative pencemaran lingkungan.

4. Diterbitkan di artikel ilmiah Universitas Muslim Nusantara Al- Washliyah

\section{METODE PELAKSANAAN}

\subsection{Waktu dan Tempat Pelaksanaan}

Program kreatifitas

masyarakat ini akan dilaksanakan di Desa Doulu Kecamatan Brastagi, Kabupaten Karo.

\subsection{Pelaksanaan Pelatihan}

Kegiatan

\section{Tahap Persiapan}

$\begin{array}{cr}\text { Sebelum melakukan } \\ \text { Program } & \text { Pengabdian }\end{array}$

Masyarakat ini, pelaksana kegiatan melakukan perijinan ke Kepala Desa Doulu mengenai pelaksanaan kegiatan. Kemudian melakukan persiapan tempat, alat dan bahan sekaligus materi tentang wirausaha dan pembuatan kerajinan tangan berbahan baku kertas yang tidak terpakai.

2. Tahap Pelaksanaan Kegiatan Pelatihan kreasi dalam upaya pemanfaatan barang bekas menjadi kerajinan tangan yang bernilai ekonomi ini akan dilaksanakan melalui beberapa tahap:

a. Sosialisasi Program

Sosialisasi program dilaksanakan setelah tahap persiapan selesai yaitu dengan melakukan pertemuan dengan calon peserta yang mengikuti pelatihan kreasi ini dan mensosialisasikan tentang program yang akan di laksanakan.

b. Penyampaian Materi

Pada tahap ini peserta akan diberikan materi seputar kewirausahaan dan cara membuat kerajinan tangan dengan berbahan baku kertas yang sudah tidak terpakai.

c. Pelatihan Kreasi

Pelatihan kreasi yaitu praktek pembuatan berbagai macam kerajinan tangan yang berbahan dasar kertas yang sudah tidak terpakai dengan alat dan bahan yang sudah disediakan. Praktek di damping oleh masyarakat yang bersangkutan. Kerajinan tangan berupa keranjang, dan tempat untuk menyimpan barangbarang kecil.

d. Pemanfaatan Hasil Kerajinan Tangan

Hasil dari pelatihan kreasi yang berupa kerajinan tangan seperti keranjang, tempat pensil dan lain-lain kemudian di jual 
kepada masyarakat umum seperti di pasar, toko-toko dan di tempat umum oleh peserta pelatihan kreasi sehingga bisa menciptakan peluang usaha bagi mereka untuk meningkatkan penghasilan serta melatih berwirausaha.

e. Evaluasi

Evaluasi dilakukan setelah semua tahap diatas telah terlaksana yaitu dengan meminta kritik dan saran pada peserta pelatihan kreasi mengenai pelaksanaan program.

\section{f. Penyusunan Laporan}

Merupakan tahap akhir pelaksanaan program yaitu menyusun dan membuat laporan hasil kegiatan.

\section{KELAYAKAN PERGURUAN TINGGI}

\subsection{KINERJA LP2M}

Universitas Muslim

Nusantara Al-Washliyah memiliki Lembaga Penelitian dan Pengabdian Pada Masyarakat (LP2M) yang dimana lembaga ini juga mengelola kegiatan penelitian dan pengabdian pada masyarakat sebagai salah satu fungsi dari Tri Dharma Perguruan Tinggi. Selama ini telah banyak kegiatan yang dilakukan oleh LP2M UMN-AW, seperti kegiatan bakti sosial, kunjungan kerja, praktek lapangan bagi mahasiswa, penerbitan jurnal ilmiah Kultura dan jurnal Tifa yang kandungannya memuat publikasi artikel, hasil penelitian dari para dosen baik dari UMN atau perguruan tinggi lain. Selain itu beberapa dosen di lingkungan UMN Al-Washliyah berhasil mendapatkan dukungan dana penelitian dari DIKTI baik untuk program Penelitian Dosen Pemula hingga Penelitian Hibah Kompetisi.
Lembaga Penelitian dan Pengabdian pada Masyarakat (LP2M) Universitas Muslim Nusantara Al Washliyah (UMNAW) bertanggung jawab terhadap pembinaan kegiatan-kegiatan staf pengajar (dosen) program studi di lingkungan UMN-AW yang berhubungan dengan penelitian dan pengabdian pada masyarakat.

Sebagai upaya pembinaan kepada dosen-dosen di lingkungan UMNAW khususnya di bidang Pengabdian pada masyarakat, maka LP2M di akhir tahun 2012 dan awal tahun 2013 telah melaksanakan berbagai kegiatan antara lain:

1. Menseleksi Proposal, mendanai dan memonitoring pelaksanaan Abdimas Pada bulan Agustus 2012, LP2M telah mengadakan seleksi terhadap proposal Abdimas yang masuk dan meloloskan proposal dosendosen program studi sebanyak 12 judul proposal pengabdian masyarakat dengan total dana yang yang berasal dari kas UMN-AW sebesar Rp. 53.000.000.- (lima puluh tiga juta rupiah). Selanjutnya di bulan tersebut sampai dengan bulan Oktober 2012 dilaksanakan Program pengabdian pada masyarakat oleh dosen-dosen yang proposalnya telah disetujui untuk didanai dengan melibatkan mahasiswa Program Studi dalam kegiatan tersebut.

2. Pada tahap ini LP2M memonitoring dan mensupervisi ke lokasi-lokasi kegiatan. Pelatihan Pembuatan Proposal Abdimas. Pada awal bulan April 2013 yang lalu LP2M telah mengandakan pelatihan pembuatan proposal Abdimas 
PPM yang sesuai dengan skim Dikti. Universitas Muslim Nusantara (UMN) Al-Wasliyah sebagai institusi pendidikan tinggi di daerah Sumatera Utara senantiasa mengembangkan dan menjalankan Tri Dharma Perguruan tinggi. Tidak hanya berkutat pada pengembangan pendidikan saja, tetapi juga menjalankan fungsi pengabdian pada masyarakat.

3. Menjelang akhir tahun 2013, dosen muda Universitas Muslim Nusantara (UMN) Al-Wasliyah berjumlah 23 tim berhasil memperoleh dana hibah penelitian dosen pemula tahun anggaran 2013. Prestasi yang belum pernah terjadi sebelumnya

\section{HASIL DAN LUARAN YANG} DICAPAI

$\begin{array}{lr}\text { Hasil dari } & \text { bentuk } \\ \text { pengabdian masyarakat } & \text { berupa } \\ \text { kegiatan pelatihan kreasi } & \text { upaya } \\ \text { pemanfaatan barang bekas } & \text { menjadi } \\ \text { kerajinan tangan adalah sebagai } \\ \text { berikut: }\end{array}$

1. Masyarakat lebih terampil dalam membuat kerajinan tangan berbahan dasar kertas dan memiliki kreativitas dalam memanfaatkan barang bekas.

2. Masyarakat dapat mengembangkan kreativitasnya melalui pelatihan membuat kerajinan tangan yang bernilai jual sehingga dapat meningkatkan perekonomian.

3. Masyarakat sadar akan kebersihan lingkungan sehingga dapat meminimalisir dampak negative pencemaran lingkungan.

4. Masyarakat dapat memanfaatkan pelatihan ini sebagai sarana untuk meningkatkan nilai jual sebagai salah satu daerah wisata di Sumatera Utara.

5. Diterbitkan di artikel ilmiah Universitas Muslim Nusantara Al- Washliyah

\section{RENCANA TAHAPAN BERIKUTNYA}

pengabdi merencanakan akan melanjutkan laporan pengabdian ini sampai kepada hasil danpembahasan. Sejauh ini, semua kegiatan pengabdian sudah dilakukan di Desa Doulu Kecamatan Brastagi Kabupaten Karo dan semua data yang diharapkan sudah diperoleh serta pelaksaan kegiatan sudah dilakukan.

Langkah akhir yang akan dilakukan adalah menyelesaikan pembahasan dari hasil pengabdian. Selanjutnya akan ditarik kesimpulan dan memberikan saran kepada masyarakat secara luas.

Untuk mewujudkan peran pengabdian dalam rangka memberdayakan barang-barang bekas dan mengkreasikannya menjadi barang bernilai ekonomi,maka disusunlah laporan pengabdian dalam bentuk publikasi ilmiah.

\section{KESIMPULAN DAN SARAN 7.1 KESIMPULAN}

Kesimpulan dari pelatihan kreasi ini adalah bahwa masih banyak barang barang bekas di sekitar kita yang bisa dimanfaatkan sehingga menjadi barang berguna dan bernilai ekonomi. Dengan diadakannya pelatihan kreasi ini, masyarakat mampu mengembangkan kreativitas mereka dan memanfaatkan kreativitas tersebut untuk menunjang perekonomian dan dapat menjadikannya sebagai daya tarik pengunjung karena 
keberadaannya di kecamatan Brastagi yang dikenal sebagai salah satu tujuan wisata di Sumatera Utara.

\subsection{SARAN}

Setelah melakukan pengabdian pelatihan kreasi ini, maka ada bebrapa saran yang diberikan kepada masyarakat secara luas yaitu hendaknya menumbuhkan kesadaran terhadap kebersihan lingkungan dengan memanfaatkan barang bekas menjadi barang yang berguna kembali dan bernilai jual dan menanamkan pentingnya berwirausaha sehingga masyarakat dapat menciptakan peluang usaha dengan kreativitasnya melalui pelatihan kreasi membuat kerajinan tangan dari barang bekas.

\section{DAFTAR PUSTAKA}

Husnul, Ade. 2008. Kreasi Mendaur Ulang Sampah. Depok: Arya Duta

Bakar, Marshall. 2008. Mengolah Sampah Menjadi Berkah. Bandung: CV. Sarana penunjang Pendidikan

Saeful Anwar, Nanang. 2008. Apa Yang Akan Kau Lakukan Terhadap Sampah.Bandung: Elisa Surya Dwitama 